\title{
Perspectivas educacionais em um cenário de novos suportes midiáticos
}

\author{
Amarildo Carnicel
}

\author{
Jornalista, doutor em Educação, professor da PUC-Campinas e pesquisador do CMU-Unicamp \\ amarildo@unicamp.br
}

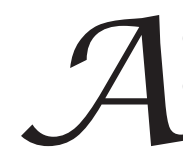
escolha do tema 'Educação para a Mídia' como principal eixo de articulação dos textos da presente edição de Resgate - Revista Interdisciplinar de Cultura deve-se à proeminência dessa área de estudos nos dias de hoje. A diversificação, a individualização e a crescente popularização dos suportes de informação, a tendência de universalização do acesso à rede web, bem como a ação cada vez mais concentrada dos grupos midiáticos, são alguns dos fatores que, por si mesmos, implicam necessária reflexão sobre o tema, sobretudo em se tratando da perspectiva educacional. Note-se, por exemplo, a tendência comum entre os jovens de informar-se táo somente a partir da internet, abandonando (ou sequer chegando a conhecer) os suportes impressos e secundarizando até mesmo a televisão. Esses movimentos, cada vez mais fortes em diferentes segmentos da sociedade moderna, motivaram o educador e professor da Unesp-Assis, Juvenal Zanchetta Junior, a reunir pesquisadores de diferentes contextos para compor a edição. Experiências vividas além de nossas fronteiras corroboram para pensar a realidade pela qual passa a juventude brasileira cada vez mais 'plugada' e, de certa maneira, pouco atenta aos suportes midiáticos tradicionais.

A amplitude do tema, por sua vez, levou à necessidade de recortes. $\mathrm{O}$ primeiro deles diz respeito à atençâo para com a educação formal. Em que pese a história consistente de iniciativas desenvolvidas pela sociedade civil e mesmo por governos na história recente, optou-se por estudos e experiências mais próximas da escola, posta a representatividade desses trabalhos no conjunto do pensamento sobre o assunto. Além disso, o país passa por momento de transição importante: em lugar de iniciativas isoladas, oriundas de setores distintos como a Comunicação, a Educação e a Psicologia, por exemplo, políticas específicas para o tema são esboçadas.

Em vista disso, um primeiro grupo de textos reporta a experiência internacional, em termos de subsídio para a consolidação da temática no Brasil. Na seçáo 'Artigos e Ensaios', os professores José Ignacio Aguaded Gómez e Ángel Hernando (Universidade de Huelva, Espanha), no trabalho "Recomendaciones para el desarrollo de la alfabetización mediática en Brasil: propuestas desde la experiencia europea”, tratam da experiência vivida no Velho Continente - um dos principais pontos de referência para a experiência brasileira desenvolvida até aqui. A professora Roxana Murdochowicz (Ministério da Educação da Argentina), em seu artigo "La educación para los medios es una educación para la democracia", promove exercício semelhante, abordando o contexto da América Latina. A entrevista concedida por Guillermo Orozco Gómez (Universidade de Guadalajara, México) ao organizador da presente edição, intitulada "Comunicação e Educação na América Latina: desafios políticos e educacionais", aborda questôes que o Brasil terá de equacionar em breve.

Um segundo grupo de artigos volta-se, de maneira geral, ao percurso da Educação para a Mídia no país. Juvenal Zanchetta faz breve histórico das políticas educacionais desenvolvidas pelo governo federal e por governos estaduais. Lígia Beatriz Carvalho de Almeida, Samir Mustapha Ghaziri (doutorandos em Educação, Unesp-Marília) e Margareth Cavalcante de Castro Lobato (Universidade Federal de Goiás) destacam ca- 
racterísticas dos trabalhos publicados nos anais das reuniōes da Associação Nacional de Pós-Graduação e Pesquisa em Educação (ANPEd), e da Sociedade Brasileira de Estudos Interdisciplinares da Comunicação (Intercom), dois dos principais fóruns de discussão dessa temática no Brasil. Raquel Lazzari Leite Barbosa (Unesp-Assis) e Rosaria de Fátima Boldarine (Unesp-Marília) tratam das representaçôes da mídia nos livros didáticos de Língua Portuguesa distribuídos pelo Ministério da Educação. Na seção 'Combates e Rituais', os livros didáticos também são objeto de estudo de João Batista Gonçalves Bueno (Fundaçáo de Ensino Superior de Bragança Paulista), em tese defendida na Faculdade de Educação da Unicamp sob a orientação da profa. Maria Carolina Bovério Galzerani.

As mestrandas em Educação (Unesp-Marília) Érika Nogueira Menegon e Angélica Maria dos Santos Oliveira assinam resenha sobre o livro Educomunicação - o conceito, o profissional, a aplicação: contribuiçóes para a reforma do Ensino Médio, do professor da ECA-USP Ismar de Oli- veira Soares. Na área do cinema, a contribuição vem do jornalista e doutor em Educação Wagner José Geribello que faz análise do filme espanhol $A$ Lingua das Mariposas, de José Luis Cuerda. Nessa reflexão, a idéia central é demonstrar que determinado viés de leitura e interpretação do filme pode levar o espectador a pensar sobre alguns aspectos da educaçáo escolar e sobre a relação entre professor e aluno.

O conjunto de textos, enfim, mesmo sem a pretensão de se colocar como 'estado da arte', destaca importantes linhas de força dessa temática no Brasil, a partir da academia, dos governos e dos materiais didáticos de maior trânsito na educação formal, bem como procura mapear alguns dos principais desafios a serem enfrentados a partir de agora. O resultado, portanto, interessa tanto aos iniciantes como também aos especialistas de diversas áreas, interessados nas relações entre Educação e Mídia. Boa leitura!

Amarildo Carnicel, editor da Revista Resgate 